\title{
Isadora Duncan Syndrome: A Case Report of Accidental Ligature Strangulation
}

\author{
Deepmalya Sengupta $^{1 *}$, Pranabesh Bharatee ${ }^{2}$, Saikat Saha $^{2}$, Rajib Prasad $^{3}$
}

${ }^{1}$ Senior Resident, ${ }^{2}$ Assistant Professor, ${ }^{3}$ Professor, Department of Forensic Medicine and Toxicology, Cooch Behar Government Medical College and Hospital, West Bengal, India

DOI: $10.36347 /$ sjams.2020.v08i08.009

| Received: 06.08.2020 | Accepted: 13.08.2020 | Published: 19.08.2020

*Corresponding author: Dr. Deepmalya Sengupta

Abstract

Way back in 1929, the accidental death of famous dancer Isadora Duncan gained a high profile. Even to this day, there are reports of accidental strangulation, though rarely. And we refer these to as Isadora Duncan syndrome. We report such a case of accidental strangulation in which the orna (dupatta) of the pillion rider got entangled into the rear wheel of a motorcycle and constricted her neck. We also intend to increase the awareness among the Indian population about the caution and care while wearing traditional clothes and drapes and the safety measures required in motorcycles/rickshaws to prevent such incidents.

Keywords: Isadora Duncan Syndrome, Ligature strangulation, Accidental, Death, Drapes.

Copyright @ 2020: This is an open-access article distributed under the terms of the Creative Commons Attribution license which permits unrestricted use, distribution, and reproduction in any medium for non-commercial use (NonCommercial, or CC-BY-NC) provided the original author and source are credited.

\section{INTRODUCTION}

Indian women use many varieties of drapes as part of their traditional attire beginning from sarees, chunni/dupatta, stoles, and scarfs to shawls and mufflers. There have been cases of accidents where these drapes have got entangled during transportation or in motorized machinery and instruments at industries or workplaces and homes. WHO as per ICD 10 defines accidents as events that are independent of human willpower, caused by an external force, happens rapidly, and results in bodily or mental damage [1]. When these clothing become entangled in some type of vehicle or mechanical device, the clothing causes progressive constriction of the neck because of the perpetual motion of the machine and leading to fatal accidents and even death[2].

A case of accidental strangulation when the orna/dupatta of a woman got entangled in the rear wheel of a motorcycle is presented here.

\section{Case History}

A 22-year-old female was brought at a subdivisional Hospital at 02:36 PM. The On duty medical officer examined her and declared her brought dead and intimated the police personnel regarding the incident and referred the body to our Cooch Behar Government Medical College and Hospital for post-mortem examination to determine the cause of death. On inquiry, as per the investigating officer, it was found that the lady was riding along with her husband on a motorcycle. She was a pillion rider and was going to her native place wearing a conventional salwar kamej with an orna around her neck. Suddenly the loose end of her orna (dupatta) got entangled in the rear wheel of the motorcycle and it twisted around her neck. Before any alarm could be raised and before her husband or the onlookers could decipher what happened and stop the bike, the lady had strangled herself to death.

\section{AUTOPSY FINDINGS}

A post-mortem examination was done on the day after the body was brought dead at the subdivisional hospital. The subject was of medium built, wheatish complexion and moderately nourished. Rigor mortis was present all over the body. On external examination, evidence of bluish discoloration was found over the nail beds, ear lobules and inner aspects of the lower lip. Petechial haemorrhages were present over the eyelids and muscles of temples on dissection. Evidence of frothy blood-stained fluid coming out from nostrils was noted. One more or less transversely placed ligature mark measuring $35 \mathrm{~cm}$ x $2 \mathrm{~cm}$, completely encircling the neck and placed low down around the neck was seen (Figure 1). The skin under the ligature mark was parchmentised and abraded and contused at places. One fresh and non-scabbed abrasion measuring $4 \mathrm{~cm} \times 3 \mathrm{~cm}$ was noted on the right palm just over the hypothenar eminence, and another fresh and non- 
scabbed abrasion measuring $6 \mathrm{~cm} \times 4 \mathrm{~cm}$ was noted over the anterolateral surface of the right knee joint. On dissection, extravasation of blood diffused in the soft tissues on the lower part of the anterior aspect of the neck was seen. The body of the thyroid cartilage was fractured with extravasations of blood in and around the fracture lines. Extensive extravasations of blood were also noted in the soft tissues over the cricoid cartilage and the upper tracheal ring. The internal organs showed generalized congestion. Multiple petechial haemorrhagic spots were found on serous membranes in the thorax, lungs (Figure 2) and the pericardium, particularly on the posterior aspect. No features of poisoning or intoxication were observed at autopsy.

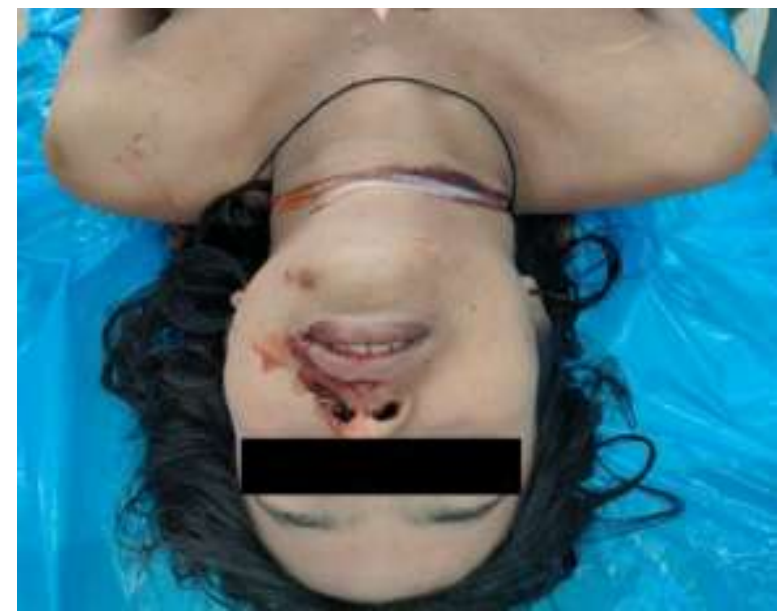

Fig-1: The deceased with the ligature mark on the neck

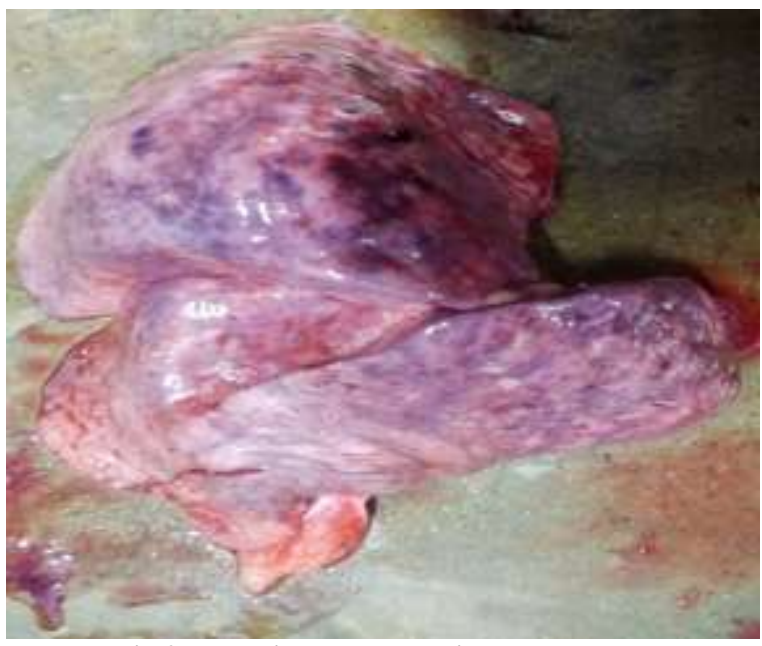

Fig-2: Petechial haemorrhagic spots on lungs

\section{DISCUSSION}

Strangulation by ligature is a type of mechanical asphyxia whereby there is a constriction of the neck from the outside by a ligature, in which the constricting force is other than the weight of the body $[3,4]$. The pressure on the neck may be affected by compressing whole or part of the circumference of the neck by a ligature [5]. Accidental strangulations are rare [6-8]. They are almost always homicidal except in the extremes of age or in otherwise healthy adults who are under the influence of drugs or alcohol or are epileptics or imbeciles [9, 10]. In some cases they have been observed in those individuals who are engaged in paraphilia or asphyxiophilia $[11,12]$.

In cases of accidental strangulation, the circumstantial evidence alone is enough to determine the accidental nature of the occurrence [13]. The first written case report of accidental strangulation in an adult was the world-famous dancer Isadora Duncan who died on 14 September 1929. The long scarf which she was wearing was caught in the wheels of her Buggati car, stopping the vehicle. Isadora died at the spot. At autopsy, she was found to have sustained a fractured larynx and carotid artery injury [14]. In the Indian context, Bhullar and Aggarwal [15] and Aggarwal and Agarwal [16] also reported a few cases of accidental ligature strangulation wherein the chunni or dupatta was entangled while moving in a vehicle like a rickshaw and a motorcycle. Cases have been reported where belts, chains or clothing have been caught in rollers or some other part of moving machinery in industries or household devices [17].

The common mechanism by which accidental ligature strangulation occurs is the progressive constriction of the neck by an article of the victim's clothing. In our case, the victim's orna got entangled in the wheels of the motorcycle. As the orna got increasingly twisted and constricted because of the continued rotational motion of the wheel, it was tightly drawn around the neck suddenly leading to instantaneous death. Most deaths in accidental ligature strangulation are instantaneous [13] and very few of them are delayed. The cause of death in ligature strangulation is usually a combined effect of asphyxia and apoplexy; however, accidental strangulation deaths can also result from compression of the neck leading to carotid sinus or vagal stimulation [18].

Usually in deaths because of strangulation, on autopsy and neck dissection, fracture of the thyroid cartilage and hyoid bone is evident. If more force is applied, there may also be a fracture of the cricoid cartilage and the tracheal rings. However, in our case, only the body of the thyroid cartilage was seen to be fractured. This is in concurrence with other studies which suggest a low incidence of hyoid bone fractures in cases of strangulation by ligature [19].

The above case reinforces the concept that strangulation though rare can occur accidentally, especially if someone with loose-fitting clothes or drapes moves in close vicinity of a moving object without proper caution. Cases of strangulation due to the entanglement of clothing into wheels of cycle rickshaw and motorcycles have been documented, and these are the popular modes of transport for the Indian population. So the need of the hour is to avoid wearing loose clothing and long drapes while travelling in 
motorcycles or cycle rickshaws or while working at a machine which has moving parts. Indian women should also be more vigilant while working in such conditions or travelling and look after their attire to prevent such mishaps. The government authorities should also make strict guidelines and provisions for the installation of safety guards and coverings over the moving parts in motorcycles/rickshaws and motorized equipment. These precautions should further help to minimize the risks of accidental strangulation.

\section{CONCLUSION}

Deaths because of accidental strangulation are a rare entity. A further few cases have been reported where long drapes of women get entangled in the wheels of motorcycles/rickshaws or machinery leading to strangulation and death. The prevention of these types of accidents often goes through straightforward yet effective measures like avoiding loose clothing or drapes while travelling in motorcycles/rickshaws and installation of coverings over the moving parts of machinery.

\section{FUNDING}

This research did not receive any specific grant from funding agencies in the public, commercial, or not-for-profit sectors.

\section{REFERENCES}

1. World Health Organisation. International Statistical Classification of Diseases and Related Health Problems (10th revision) Geneva, WHO. 1992; 1011-87.

2. Russel D, Deidiker MD. Accidental ligature strangulation due to a roller type massage device. Am J Forensic Med Pathol. 1999; 20:354-5.

3. Gordon I, Shapiro HA. Forensic medicine: a guide to principles. 2nd Ed. New York, NY: Churchill Livingstone. 1982.

4. Pillay VV. Textbook of Forensic Medicine and toxicology. 17th Ed. Hyderabad: Paras Medical Publisher. 2016: 296-325
5. Vij K. Textbook of Forensic Medicine and Toxicology: Principles and practice. $5^{\text {th }}$ ed. New Delhi: Elsevier India Pvt Ltd. 2011: 110-145.

6. McMaster AR, Ward EW, Dykeman A. Suicidal ligature strangulation: case report and review of literature. J. Forensic Sci. 2001; 46: 386-8.

7. Kohli A, Verma S.K. and Agarwal B.B.L. Accidental strangulation in a rickshaw. Forensic Sci. Int. 1996; 78: 7-11.

8. DiMaio DJ, DiMaio VJM. Forensic pathology, 2nd Ed. New York, NY: CRC Press. 1993. 273.

9. Reddy KSN, Murty OP. The essentials of forensic medicine and toxicology. $33^{\text {rd }}$ Ed. Jaypee. 2014: 350-51.

10. Aggarwal A. Textbook of Forensic Medicine and Toxicology. $1^{\text {st }}$ ed. Avichal Publishing Company. 2016: 366-92.

11. Behrendt M. and Modvig J. The lethal paraphiliac syndrome. Am. J. Forensic Med. Pathol. 1995; 16: 232-7.

12. Uva JL. Review: autoerotic asphyxiation in the United States. J. Forensic Sci 1995; 40: 574-81.

13. Ambade VN, Godbole HV, Dixit PG, Kukde HG. Accidental ligature strangulation due to crop thrasher. J Forensic Leg Med. 2008; 15(4):263- 5.

14. Gowens PA, Davenport RJ, Kerr J, Sanderson RJ, Marsden AK. Survival from accidental strangulation from a scarf resulting in laryngeal rupture and carotid artery stenosis: the Isadora Duncan syndrome. A case report and review of literature. Emerg Med J. 2003; 20:391-3.

15. Bhullar DS, Aggarwal OP. A rare case of accidental strangulation-a case studies. J Forensic Med Toxicol. 1997; 14(2):26.

16. Aggarwal NK, Agarwal BB. Accidental strangulation in a cycle rickshaw. Med Sci Law 1998; 38:263-5.

17. Shetty M, Shetty BS. Accidental ligature strangulation due to electric grinder. J Clin Forensic Med. 2006; 13(3):148-50.

18. Knight B. Legal aspects of medical practice. London: Churchill Livingstone; 1992.

19. Ubelaker DH. Hyoid fracture and strangulation. J. Forensic Sci. 1992; 37: 1216-22. 